\title{
EFEK SITOTOKSIK EKSTRAK ETANOLIK HERBA SELEDRI (Apium graveolens L.) PADA SEL KANKER T47D, WiDr, DAN HeLa
}

\section{Kartika Dyah Palupi, Ainun Wulandari, Fina Aryani Goenadi, Kholid Alfan Nur, Aditya Fitriasari dan Edy Meiyanto*}

\author{
Cancer Chemoprevention Research Center \\ * Korespodensi : \\ Prof. Dr. Edy Meiyanto, Msi., Apt. \\ e-mail: meiyan_e@ugm.ac.id \\ http://ccrc.farmasi.ugm.ac.id
}

Fakultas Farmasi, Universitas Gadjah Mada, Yogyakarta

\begin{abstract}
ABSTRAK
Seledri (Apium graveolens L.) telah lama digunakan oleh masyarakat sebagai penurun tekanan darah, antirematik, obat penenang, diuretik ringan, antiseptik pada saluran kemih, antioksidan, dan antiinflamasi. Penelitian terdahulu menyebutkan bahwa beberapa kandungan fitokimia yang terdapat dalam seledri seperti apigenin dan luteolin memiliki efek sitotoksik terhadap beberapa tipe sel kanker. Namun penelitian mengenai efek sitotoksik ekstrak etanolik herba seledri (EES) pada sel kanker payudara (T47D), sel kanker kolon (WiDr), dan sel kanker leher rahim (HeLa) belum dilakukan. Oleh karena itu penelitian ini bertujuan untuk mengetahui efek sitotoksik EES terhadap ketiga sel tersebut.

Uji sitotoksisitas dilakukan dengan menggunakan MTT assay dan serapannya dibaca dengan ELISA reader pada $\lambda=595 \mathrm{~nm}$. Hasil yang diperoleh memperlihatkan bahwa EES mampu menurunkan viabilitas sel Hela pada rentang kadar 100-750 $\mu \mathrm{g} /$ ml, sedangkan pada sel T47D dan WiDr, EES baru menurunkan viabilitas sel pada rentang konsentrasi $500-750 \mu \mathrm{g} / \mathrm{ml}$. Berdasarkan peneletian ini, EES berpotensi dikembangkan sebagai agen pencegahan dan pengobatan untuk penyakit kanke terutama kanker leher rahimr.
\end{abstract}

Kata kunci : sitotoksisitas, HeLa, WiDr, T47D, seledri (Apium graveolens L.)

\section{ABSTRACT}

Celery (Apium graveolens L.) is commonly used to lower blood pressure, antirheumatic, relaxant, mild diuretic, antiseptic for the urinary tract, antioxidant, and anti-inflammation. According to previous studies, a number of the phytochemicals found in the plant show cytotoxicity toward some types of cancer cells. However, studies on the cytotoxic effects of celery herb ethanolic extract (CEE) on breast cancer cell (T47D), colon cancer cell (WiDr), and cervix cancer cell (HeLa), however, has not been done yet. Our research aims at doing so. 
Cytotoxicity test was conducted using MTT assay and its absorbance was read using ELISA reader at $\lambda=595 \mathrm{~nm}$. Results of the assay show that CEE reduces cell viability at concentrations of 100-750 $\mu \mathrm{g} / \mathrm{ml}$ on HeLa cells, while reduction of T47D and WiDr cell viability was not achieved until concentrations of 500-750 $\mu \mathrm{g} / \mathrm{ml}$. Based on these results, we conclude that CEE hold many potentials for further developments as preventive and therapeutive agent in cancer treatment.

Kata kunci : Cytotoxicity, HeLa, WiDr, T47D, celery (Apium graveolens L.)

\section{PENDAHULUAN 6}

Kanker merupakan salah satu penyebab kematian utama di dunia dan menyebabkan sekitar 7,4 juta kematian pada tahun 2004. Kematian akibat kanker diperkirakan terus meningkat dan mencapai angka 12 juta kematian pada tahun 2030 (1). Di Indonesia, terdapat dua macam kanker yang banyak menyerang wanita, yaitu kanker leher rahim dan kanker payudara (2). Kanker leher rahim merupakan penyebab kematian yang terbesar pada wanita di negara-negara berkembang, bahkan tiap tahunnya sekitar seperempat juta wanita meninggal karena penyakit ini (3). Suatu data pada tahun 2007, menyebutkan bahwa kanker payudara menempati urutan ke lima di dunia sebagai penyebab kematian akibat kanker (4). Selain kanker payudara dan leher rahim, kanker yang memiliki tingkat insidensi tinggi adalah kanker kolon. Kanker kolon menempati peringkat tiga besar penyakit kanker setelah kanker payudara dan kanker paru-paru di Amerika (5).

Terapi kanker yang banyak digunakan hingga saat ini adalah pembedahan, kemoterapi dan radioterapi (68) . Pada beberapa tahun terakhir ini imunoterapi juga dikembangkan untuk terapi terhadap kanker (9). Pembedahan merupakan terapi kanker yang cenderung aman, namun tidak semua jenis kanker bisa diobati dengan cara ini (10) sedangkan kemoterapi dan radioterapi memiliki efek samping yang cukup merugikan seperti penerunan system kekebalan tubuh sehingga pasien rentan terkena infeksi (11). Oleh karena itu perlu dilakukan pengembangan pemanfaatan bahan alam sebagai alternatif pengobatan kanker untuk mengurangi efek samping dari pengobatan yang selama ini telah digunakan.

Salah satu bahan alam yang memiliki prospek sebagai alternatif pengobatan kanker adalah seledri. Seledri merupakan salah satu tanaman yang mengandung 4',5,7, trhydroxyflavone (apigenin), suatu senyawa flavonoid, dengan jumlah tinggi (12). Penelitian yang telah dilakukan menunjukkan bahwa apigenin dapat menyebabakan cell cycle arrest pada fase $\mathrm{G} 2 / \mathrm{M}$ pada sel kanker payudara MDA-MB231 (13). Sebuah penelitian menyebutkan bahwa apigenin menekan jalur PI3K/Akt yang berperan dalam pertahanan sel kanker payudara melalui penghambatan aktivasi Akt dengan menghambat secara langsung aktivitas PI3K (14). Selain apigenin, seledri juga mengandung luteolin yang dapat menginduksi apoptosis pada sel kanker oral squamus SCC-4 (15). Berdasarkan datadata tersebut sangat menarik untuk meneliti apakah ekstrak etanolik herba seledri memiliki aktivitas sitotoksik terhadap beberapa jenis sel kanker yaitu sel kanker payudara T47D, sel kanker kolon WiDR, serta sel kanker leher rahim HeLa sehingga dapat digunakan sebagai alternative pengobatan kanker yang potensial. 


\section{TUJUAN}

Penelitian ini dilakukan untuk mengetahui efek sitotoksik ekstrak etanolik herba seledri (EES) terhadap sel kanker payudara (T47D), kanker kolon (WiDr), dan kanker leher rahim (HeLa).

\section{METODE}

\section{Bahan}

Herba seledri (Apium graveolens L.), sel kanker T47D, HeLa, dan WiDr (koleksi Cancer Chemoprevention Research Center, Fakultas Farmasi Universitas Gadjah Mada), DMEM (Dulbecco's modified Eangle's medium) dan Roswell Park Memorial Institute 1640 (RPMI 1640, Gibco) yang mengandung Fetal Bovine Serum (FBS) $10 \%$ v $/ \mathrm{v}$ (Gibco), penisillinstreptomisin $(10.000$ unit/mL Penisilin, $10.000 \mu \mathrm{g} / \mathrm{mL}) 1 \%$ v ${ }_{\mathrm{v}}$ (Gibco), DMSO digunakan untuk melarutkan stok ekstrak uji dengan konsentrasi tidak lebih dari $2 \%$, tripsin-EDTA $0,25 \%$ untuk membantu melepas sel yang melekat pada flask maupun dish.

Alat

Alat maserasi, rotary evaporator, treated tissue culture dish diameter $10 \mathrm{~cm}$ (Iwaki), konikal $15 \mathrm{ml}$ steril (Falcon), eppendorf (Brand), yellow tip (Brand), blue tip (Brand), timbangan (Sartorius), inkubator $\mathrm{CO}_{2}$ (Heraceus), sentrifus (Sorvall), Laminar air flow cabinet (Labconco), mikropipet (Gilson), autoklaf (Hirayama), haemositometer (Nebauer), mikroskop inverted (Zeiss), ELISA reader (Bio-Rad), 96-well plate (Nunc), shaker (Gemmy), dan kamera digital (Nikon, Coolpix 5,0 mega pixels).

\section{Ekstrak Etanolik Herba Seledri (EES)}

Herba seledri diperoleh dari daerah Tawangmangu, Karanganyar, Surakarta, Jawa Tengah. Seluruh bagian herba digunakan dalam pembuatan ekstrak etanolik. Herba kemudian dikeringkan, diserbuk, dan diekstraksi dengan maserasi menggunakan etanol 70\%. Setiap 100 gram serbuk diekstraksi menggunakan 1 Liter etanol $70 \%$. Maserat kemudian diuapkan dengan rotary evaporator untuk memperoleh ekstrak kental.

\section{Kultur Sel}

Sel WiDr, HeLa, dan T47D yang digunakan dalam penelitian ini merupakan koleksi dari Cancer Chemoprevention Research Center (CCRC) yang diperoleh dari Prof. Tatsuo Takeya (Nara Institute of Science and Technology, Japan). Sel ditumbuhkan dalam media kultur yang terdiri dari medium Dulbecco's modified Eagle's (DMEM; Gibco) untuk sel HeLa dan T47D sedangkan untuk sel WiDr digunakan medium Roswell Park Memorial Institute 1640 (RPMI 1640, Gibco), 10\% fetal bovine serum (FBS; Gibco), dan Penicillin-Streptomycin (10.000 unit/mL Penisilin, $10.000 \mu \mathrm{g} / \mathrm{mL}$ ) 1\% $\%$ (Gibco)). Sel diinkubasi dalam inkubator $\mathrm{CO}_{2} 5 \%$, $37^{\circ} \mathrm{C}$.

\section{Uji sitotoksik}

Sel WiDr, HeLa dan T47D dengan kepadatan 5 x $10^{3} \mathrm{sel} / \mathrm{sumuran}$ didistribusikan ke dalam 96-well plate sumuran dan diinkubasi selama 24 jam pada $37^{\circ} \mathrm{C}$ agar beradaptasi dan menempel di dasar sumuran. Setelah 24 jam (sel telah konfluen) media diibuang, kemudian ditambahkan $100 \mu 1$ media kultur (kontrol) atau EC dengan konsentrasi 1, 10, 50, 100, 250, 500, dan $750 \mu \mathrm{g} / \mathrm{ml}$ dan diinkubasi kembali selama 24 jam dalam inkubator $\mathrm{CO}_{2}$ $5 \%, 37^{\circ} \mathrm{C}$. Pada akhir inkubasi, media dibuang, dicuci menggunakan PBS (Sigma), kemudian ke dalam masing-masing sumuran ditambahkan $100 \mu \mathrm{l}$ media kultur yang mengandung $5 \mathrm{mg} / \mathrm{ml}$ MTT, diinkubasi lagi selama 4 jam pada suhu $37^{\circ} \mathrm{C}$. Sel yang hidup akan bereaksi dengan MTT membentuk kristal formazan. Reaksi 
dihentikan menggunakan Sodium Dodecyl Sulfate (SDS) $10 \%$ dalam HCL 0,1 N. Plate kemudian dibungkus dengan aluminium foil dan diinkubasi dalam tempat gelap pada suhu kamar selama satu malam. Setelah inkubasi, plate digoyang dengan shaker selama 10 menit agar kristal formazan larut kemudian dibaca absorbansinya dengan ELISA reader pada panjang gelombang 595 nm.

\section{Analisis Data}

Data yang diperoleh berupa absorbansi dari masing-masing sumuran dikonversi ke dalam persen sel hidup menggunakan Excell MS Office 2003. Persen sel hidup dihitung menggunakan rumus:

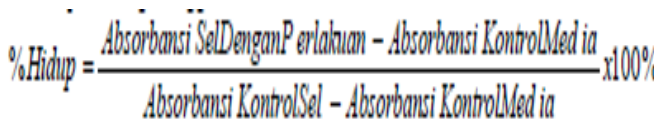

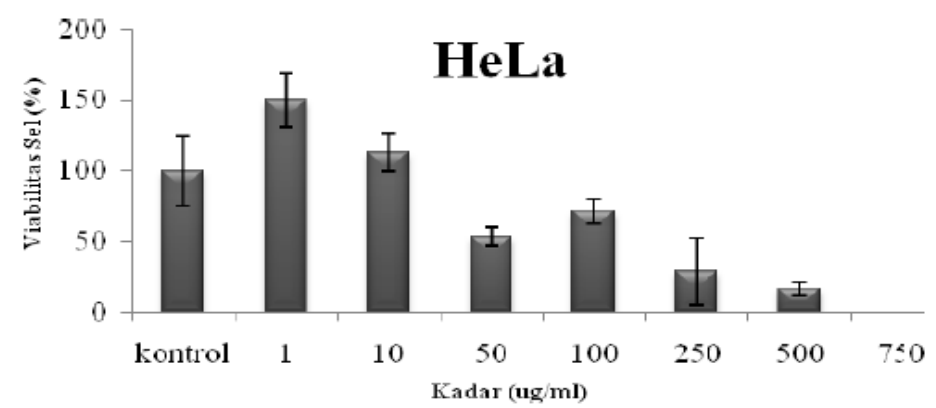

(A)

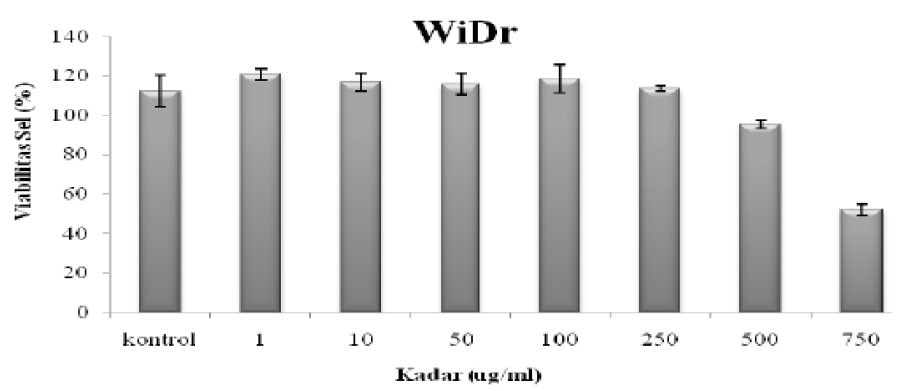

(B)

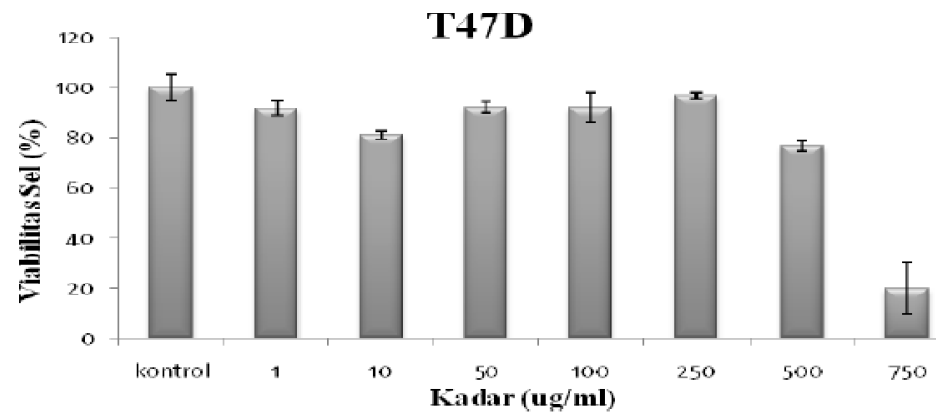

(C)

Gambar 1. Efek EES terhadap viabilitas sel HeLa (A), WiDr (B), dan T47D (C). EES menurunkan viabilitas sel HeLa pada mulai konsentrasi $50 \mu \mathrm{g} / \mathrm{ml}$, sedangkan pada sel T47D dan WiDr penurunan viabilitas sel terjadi pada konsentrasi EES 500-750 $\mu \mathrm{g} / \mathrm{ml}$. Sensitivitas sel Hela terhadap EES paling tinggi diikuti oleh sel T47D dan WiDr. Sel HeLa, T47D, dan WiDr sebanyak $5 \times 10^{3}$ sel tiap sumuran ditanam pada 96 well plate kemudian diinkubasi dengan EES konsentrasi 1 , $10,50,100,250,500,750 \mu \mathrm{g} / \mathrm{ml}$ selama 24 jam pada $37^{\circ} \mathrm{C}$. Viabilitas sel diukur menggunakan metode MTT. 
HASIL DAN PEMBAHASAN

EES menurunkan viabilitas sel Hela, T47D, dan WiDr

Pada penelitian ini dilakukan uji sitotoksik dari EES terhadap sel HeLa, T47D dan WiDr dengan MTT assay. Parameter sitotoksik yang digunakan adalah kemampuan konversi subtrat MTT menjadi formazan oleh enzim suksinatdehidrogenase. Reaksi reduksi MTT menjadi formazan hanya dapat dilakukan oleh sel hidup. Dengan demikian, absorbansi dari formazan yang terbentuk berbanding lurus terhadap viabilitas populasi sel (16). Hasil penelitian ini menunjukkan bahwa tiap sel memiliki sensitifitas yang berbeda terhadap EES sehingga efek sitotoksik EES pada tiap sel juga berbeda (gambar 1).

Berdasarkan data yang diperoleh, sel HeLa memiliki sensitifitas yang paling tinggi terhadap EES diikuti oleh sel T47D dan WiDr. Pada sel HeLa, EES menyebabkan penurunan viabilitas sel mulai konsentrasi $100 \mu \mathrm{g} / \mathrm{ml}$ dan pada konsentrasi $750 \mu \mathrm{g} / \mathrm{ml}$ seluruh sel mati. Sedangkan pada sel T47D dan WiDr penurunan viabilitas sel yang cukup tajam baru terjadi pada konsentrasi EES500-750 $\mu \mathrm{g} / \mathrm{ml}$. Pada konsentrasi $750 \mu \mathrm{g} / \mathrm{ml}$, viabilitas deri sel T47D turun hingga lebih dari 20\% sedangkan sel WiDr viabilitasnya turun hingga $52 \%$.

Pada kanker serviks secara umum, p53 mengalami penurunan fungsi karena protein E6 yang dihasilkan oleh HPV akan mengikat p53, kemudian mendegradasinya (17). Oleh karena itu pada sel HeLa normal tanpa perlakuan, protein p53 tidak akan terekspresi. Apium graveolens L. merupakan salah satu tanaman dengan kandungan flavonoid apigenin tertinggi (12). Berdasarkan penelitian yang telah dilakukan, apigenin menyebabkan G1 arrest pada sel HeLa dan menginduksi apoptosis bergantung p53 yang ditandai dengan naiknya ekspresi protein p21/WAF1 dan juga induksi dari ekspresi Fas/APO-1 serta caspase-3 (18). Oleh karena itu, efek perlakuan EES dimungkinkan mampu menurunkan viabilitas sel HeLa melalui pemacuan apoptosis yang bergantung protein p53. Namun masih perlu dilakukan penelitian lebih lanjut mengenai hal ini.

Pada sel payudara T47D, terlihat bahwa penurunan viabilitas sel yang tajam baru terlihat pada konsentrasi EES $750 \mu \mathrm{g} /$ ml. Hal ini menunjukkan bahwa sel HeLa lebih sensitif terhadap EES dibanding dengan sel T47D. Hal ini dimungkinkan karena p53 dari sel T47D mengalami mutasi, sedangkan pada sel HeLa tidak terjadi mutasi, sehingga dimungkinkan pemacuan apoptosis pada sel HeLa lebih baik dari pada sel T47D. Sel T47D merupakan sel kanker payudara ER/PR-positif yang mengekspresikan caspase 3 wildtype, caspase 7 wildtype dan p53 mutan. Misssence mutation terjadi pada residu 194 (dalam zinc-binding domain, L2), sehingga p53 tidak dapat berikatan dengan response element pada DNA. Hal ini mengakibatkan berkurang bahkan hilangnya kemampuan p53 untuk regulasi siklus sel $(19,20)$ pada sel T47D sehingga dimungkinkan sel HeLa lebih sensitive terhadap EES dibanding sel T47D.

Tabel 1. Penurunan Viabilitas Sel Setelah Perlakuan dengan EES

\begin{tabular}{ccc}
\hline Jenis Sel & Konsentrasi EES & $\begin{array}{c}\% \text { Penurunan } \\
\text { Viabilitas Sel }\end{array}$ \\
\hline $\mathrm{HeLa}$ & $250 \mu \mathrm{g} / \mathrm{ml}$ & $70,98 \%$ \\
$\mathrm{WiDr}$ & $750 \mu \mathrm{g} / \mathrm{ml}$ & $47,86 \%$ \\
$\mathrm{~T} 47 \mathrm{D}$ & $750 \mu \mathrm{g} / \mathrm{ml}$ & $80,09 \%$ \\
\hline
\end{tabular}


Penurunan viabilitas sel T47D pada konsentrasi EES $750 \mu \mathrm{g} / \mathrm{ml}$ dapat terjadi karena beberapa kemungkinan selain melalui apoptosis yang bergantung p53. Sebuah penelitian menyebutkan bahwa pada kadar tinggi, apigenin dapat menghambat pertumbuhan sel kanker payudara MCF7 dengan menurunkan level protein ER $\alpha$ dan A1B1 (21). Sel T47D dan MCF7 merupakan sel payudara ER $\alpha+$ sehingga apa yang terjadi pada sel MCF7 juga dimungkinkan terjadi pada sel T47D.Selain melalui jalur yang bergantung Era, penurunan viabilitas sel T47D juga dimungkinkan melalui jalur lain seperti jalur kinase. Penelitian tersebut juga menyebutkan bahwa apigenin dapat menghambat protein p38, MAPK, PKA, dan AKT/PI3K pada sel kanker payudara (21). Penghambatan pada protein-protein tersebut akan menyebabkan terjadinya hambatan pada pertumbuhan sel kanker. Walaupun begitu, penelitian lebih lanjut diperlukan untuk mengetahui mekanismenya dengan lebih jelas.

Pada dosis EES hingga $250 \mu \mathrm{g} / \mathrm{ml}$ tidak tampak adanya penurunan viabilitas sel. Aktivitas apigenin pada sel kanker payudara merupakan aktivitas yang bergantung dosis, bahkan disebutkan bahwa pada kadar rendah apigenin dapat menstimulasi pertumbuhan sel kanker ER $\alpha+$ dengan mempromosikan A1B1 untuk berikatan dengan Er $\alpha$ pada sel MCF7 (21). Kandungan apigenin pada EES dengan kadar 1-250 $\mu \mathrm{g} / \mathrm{ml}$ dimungkinkan rendah sehingga pada kadar tersebut viabilitas sel T47D masih tinggi.

Pada sel WiDr, terlihat bahwa penurunan viabilitas sel baru terjadi pada konsentrasi EES 500-750 $\mu \mathrm{g} / \mathrm{ml}$ sama hal nya dengan T47D. Namun penurunan viablitas sel WiDr lebih rendah dibanding T47D. WiDr merupakan sel dengan ekspresi COX-2 yang tinggi (22). Hal ini memungkinkan viabiltas sel yang tinggi pada perlakuan EES dengan dosis dibawah 500 $\mu \mathrm{g} / \mathrm{ml}$ karena pada dosis tersebut EES belum mampu menekan ekspresi CoX-2. Ekspresi COX-2 tinggi yang memacu proliferasi sel WiDr. Selain itu, pada sel WiDr terjadi mutasi p53 pada posisi 273 sehingga terjadi perubahan residu arginin menjadi histidin (23). Mutasi pada p53 menyebabkan gangguan pemacuan apoptosis pada sel WiDr. Walaupun demikian masih ada kemungkinan penghentian daur sel pada sel WiDr. Sebuah penelitian mengatakan bahwa p21 pada sel WiDr yang masih normal memungkinkan untuk terjadinya penghentian daur sel (24). EES dimungkinkan memacu penghentian daur sel melalui p21 sehingga terjadi penurunan viabilitas sel WiDr pada hingga hampir 50\% pada konsentrasi $750 \mu \mathrm{g} / \mathrm{ml}$. Studi lebih lanjut diperlukan untuk mengklarifikasi kemungkinan mekanisme molekuler dari EES ini.

Keseluruhan penelitian ini memunculkan pemikiran bahwa EES mampu menurunkan viabilitas sel kanker tertentu. Fakta tersebut membuka peluang pengembangan EES sebagai agen kemoterapi maupun kokemoterapi namun tidak lepas dari diperlukannya penelitian lebih lanjut untuk menelusuri mekanisme molekulernya.

\section{KESIMPULAN.}

EES mampu menurunkan viabilitas sel Hela pada rentang kadar $100-750 \mu \mathrm{g} / \mathrm{ml}$, sedangkan pada sel T47D dan WiDr, EES baru menurunkan viabilitas sel pada rentang konsentrasi 500-750 $\mu \mathrm{g} / \mathrm{ml}$.

\section{DAFTAR PUSTAKA}

World Health Organization: Cancer; 2009.

Dalimartha S. Kandungan Nutrisi \& Bioaktif Tahitain Noni Juice Membantu Mengatasi Kanker Payudara. Women Health Cancer dan Health Talk; 2008. 
Garcia M, Jemal A, Ward EM, Center MM, Hao Y, Siegel RL, and Thun MJ. Global Center Facts \& Fiures 2007. Atlanta, GA: American Cancer Society; 2007.

WHO. Fact Sheet No.297: Cancer; 2007. Diambil dari situs http:// www.who.int/mediacentre/ factsheets/fs297/en/index.html, diakses Januari 2009.

Jemal A, Siegel R., Ward E, Hao Y, Xu J, and Thun, M.J. Cancer Statistics. CA Cancer J Cli. 2009;59:225249.

Jhanwar YS, and Divgi C. Current Status of Therapy of Solid Tumors. J Nucl Med. 2005;46: 141S-150S.

Abou-Jawde R, Choueiri T, Alemany C, and Mekhail, T. An Overview of Targeted Treatments in Cancer. Clin Ther. 2003;25: 2121-2137.

Guillemard V, and Saragovi HU. Novel Approaches for Targeted Cancer Therapy. Curr Cancer Drug Targets. 2004;4:313-326.

Antonia S, Mule JJ., and Weber JS. Current Developments of Immunotherapy in the Clinic. Curr Opin Immunol. 2004;16:130-136.

Miner TJ. Palliative surgery for advanced cancer: lessons learned in patient selection and outcome assessment. Am J Clin Oncol. 2005;28:411-414.

Elshaikh M, Ljungman M, Ten Haken R, and Lichter AS. Advances in Radiation Oncology. Annu Rev Med; 2005.

Patel D, Shukla S, Gupta S. Apigenin and Cancer chemoprevention: Progress, Potensial, Promise (Review).
International Journal of Oncology. 2007;30: 233-245.

Yin F, Giuliano AE, Law RE, and van Herle AJ. Apigenin Inhibits Growth and Induces G2/M Arrest by Modulating Cyclin-CDK Regulators and ERK MAP Kinase Activation in Breast Carcinoma Cells. Anticancer Res. 2001;21:413-420.

Way TD, Kao MC, and Lin JK. Degradation of HER2/neu by Apigenin Induces Apoptosis Through Cytochrome $\mathrm{C}$ Release and Caspase-3 Activation in HER2/neu-Overexpressing Breast Cancer Cells. FEBS Lett. 2005;579: 145-152.

Yang SF, Yang WE, Chang HR, Chu SC, and Hsieh YS. Luteolin Induces Apoptosis in Oral Squamous Cancer Cells. J DENT RES. 2008;87: 401

Mosmann, T. Rapid Colorimetric Assay for Cellular Growth and Survival: Application to Proliferation and Cytotoxicity Assays. Journal of Immunological Methods. 1983;65(1-2):55-63.

DeFillippis RA, Goodwin EC, Wu L, DiMaio D. Endogenous Human Papillomavirus E6 and E7 Proteins Differentially Regulate Proliferation, Senescence, and Apoptosis in Hela Cervical Carcinoma Cells. Journal of Virology. 2003;77(2):1551-1563.

Zheng PW, Chiang LC, and Lin CC. Apigenin Induced Apoptosis through p53-dependent Pathway in Human Cervical Carcinoma Cells. Life Sci. 2005;76: 1367-1379.

Bouker KB, Skaar TC, Riggins RB, Harburger DS, Fernandez DR, 
Zwart A, Wang A, and Clarke R. Interferon regulatory factor-1 (IRF-1) Exhibits Tumor Suppressor Activities in Breast Cancer Associated with Caspase Activation and Induction of Apoptosis. Carcinogenesis. 2005;26(9):1527-1535.

Schafer JM, Lee ES, O'Regan RM, Yao $\mathrm{K}$, and Jordan VC. Rapid Development of Tamoxifenstimulated Mutant p53 Breast Tumors (T47D) in Athymic Mice. Clin. Can. Res. 2000;6:43734380.

Long X, Fan M, Bigsby RM, and Nephew KP. Apigenin Inhibits Antiestrogen-Resistant Breast Cancer Cell Growth through Estrogen Receptor- $\alpha$-Dependent and Estrogen Receptor- $\alpha$ Independent Mechanisms. Mol Cancer Ther. 2008;7(7): 20962108.

Palozza P, Serini S, Maggiano N, Giuseppe T, Navarra P. Carotene Downregulates the Steady-State and $\beta$ Ranelletti, F.O. Heregulin-aInduced COX-2 Pathways in Colon Cancer Cells. J.Nutr. 2005;135:129-136.

Noguchi P, Wallace R, Johnson J, Early EM, O'Brien S, and Ferrone S. Characterization of the WiDr: a Human Colon Carcinoma Cell Line. In Vitro. 1979;15(6):401408.

Liu HC, Chen GG, Vlantis AC, Leung BCS, Tong MCE, and van Hasselt CA. 5-Fluorouracil Mediates Apoptosis and G1/S Arrest in
Laryngeal Squamous Cell Carcinoma via a p53-Independent Pathway. The Cancer Journal. 2006;12(6):482-493. 